\title{
Metatarsus primus varus の起源について
}

— X 線写真計測による解析の試み

\author{
久留米大学整形外科 \\ 西 見 文 紀
}

市立戸畑病院整形外科

河 野 邦 治

\section{The Etiology of Metatarsus Primus Varus An Attempt to Analyze Radiographs}

by

\section{Fumiki Nishimi}

Department of Orthopaedic Surgery, School of Medicine,

Kurume University, Kurume

\section{Kuniharu Kawano}

Department of Orthopaedic Surgery, Municipal Tobata Hospital

The etiology of metatarsus primus varus and its relation to hallux valgus has not been established conclusively. We analyzed radiographs of 119 cases with complaints in their feet by measuring intermetatarsal angle and hallux valgus angle. As a result, metatarsus primus varus occurs secondarily to the increase of hallux valgus angle. And the cause of hallux valgus has an influence on both the increase of hallux valgus angle and the increase of intermetatarsal angle.

\section{緒}

言

外反母趾の成因のひとつとして, metatarsus primus

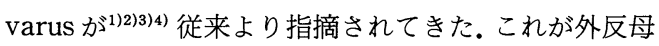
趾に対して，一次的に現われるのか，二次的に現われ るのかを調べるために，X線写真の計測を行った。

\section{対 象}

対象は, 昭和 61 年度に市立戸畑病院を受診した足部 に愁訴をもつ患者のうち, 119 例, 119 足である.その 内訳は, 男 56 例, 女 63 例, 初診時年令は 2 才から 84 才までで, 平均年令は 38.4 才であった.

\section{方}

\section{法}

計測法は, metatarsus primus varus の指標として intermetatarsal angle を, また外反母趾の指標として hallux valgus angleを各々計測した（図1, 図 2).

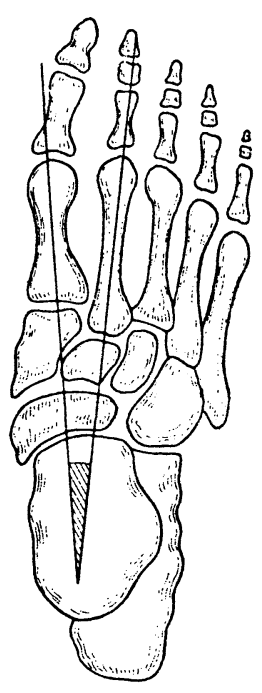

図 1 Intermetatarsal angle 


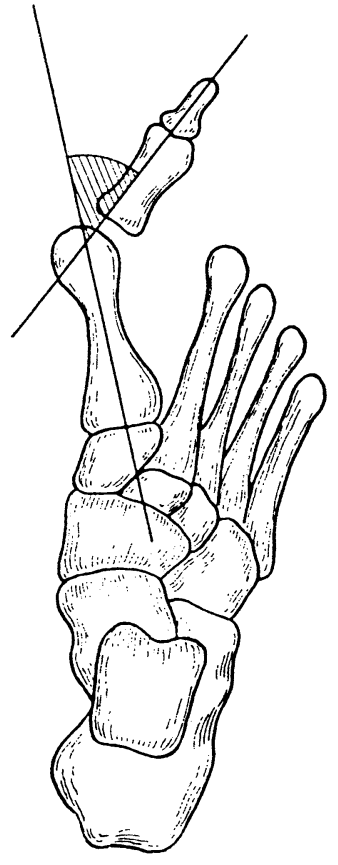

図 2 Hallux valgus angle

結果は, intermetatarsal angle の平均値と標準偏差 は $10.3 \pm 3.3^{\circ}$, hallux valgus angle $の$ 平均值と標準偏 差は $14.8 \pm 7.2^{\circ}$, 相関係数は 0.47 であった.両者の間 に線形相関の関係はなかった。

さらに 10 才毎に年令群をつくり,各群における inter metatarsal angle と hallux valgus angle の平均値と 相関係数を求めた。結果は図 3 のごとく, hallux valgus angle が 10 才以下で有意に低かったが, 他の年令群に おいては intermetatarsal angleも hallux valgus angle も統計学的に有意の差はなかった。また各群にお ける inter-metatarsal angle と hallux valgus angle との間の相関係数は低く,線形相関の関係はなかった. すなわち，年令的に差はなかったということになるの で, intermetatarsal angle と hallux valgus angle が 各々平均值 $+1.6 \alpha$ 以上のものを集めて T検定を行っ た。

まず, intermetatarsal angle が平均值 $+1.6 \alpha$ 以上, すなわち $16^{\circ}$ 以上のもの，12 例では, hallux valgus angle の平均値と標準偏差は $20.6 \pm 6.7^{\circ}$, 両者の相関係 数は 0.79 であった. intermetatarsal angle は hallux valgus angle に対して有意水準 $1 \%$ そも差ありとなっ
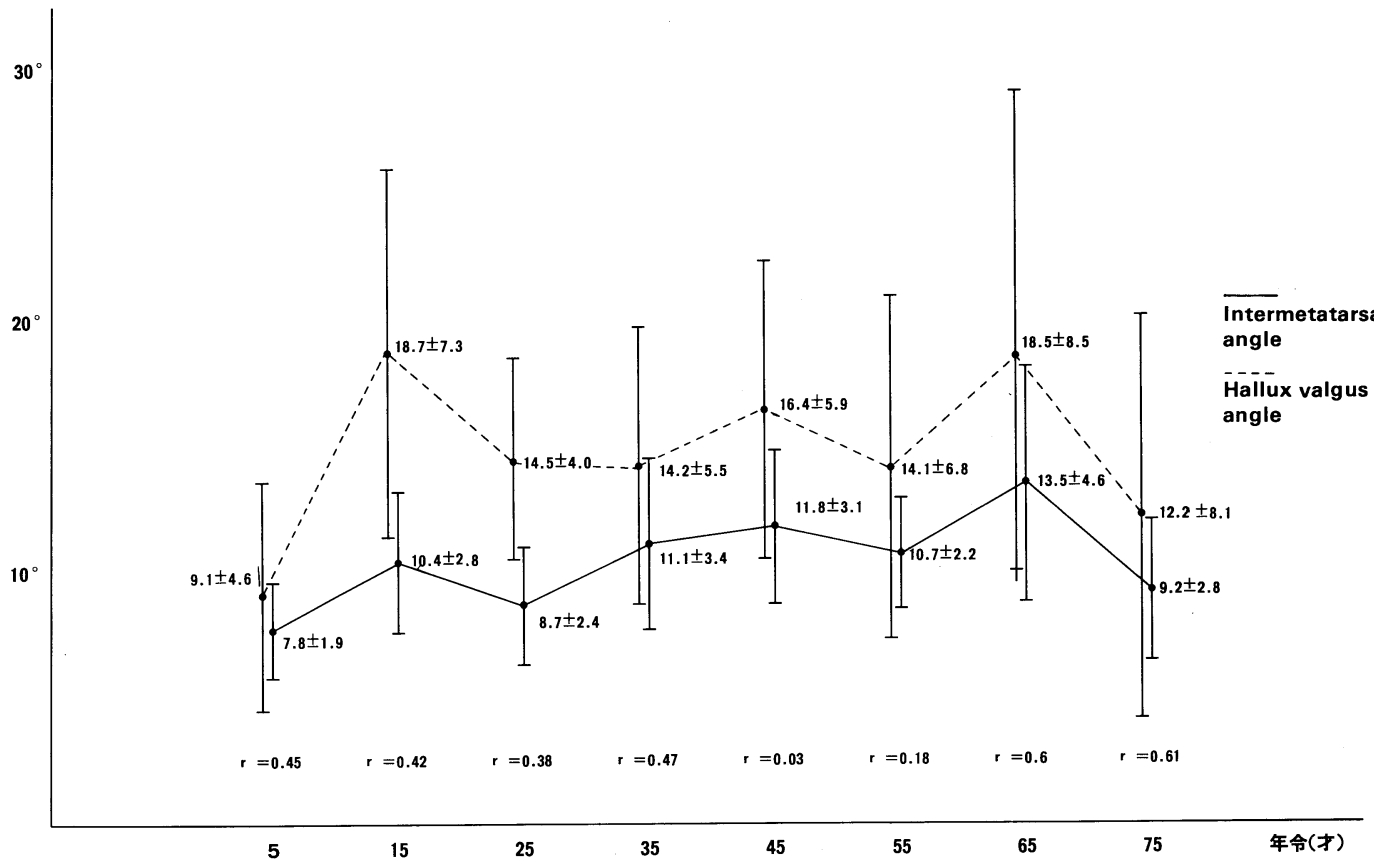

図 3 各年令群における平均值, 標準偏差および相関係数 
た。すなわち hallux valgus angle が有意に大きくな り，正の相関関係が強いことがわかった。

一方, hallux valgus angle が, 平均值 $+1.6 \alpha$ 以上 のもの，すなわち $27^{\circ}$ 以上のもの，6 例では, intermet atarsal angle の平均值と標準偏差は $14.5 \pm 4.6^{\circ}$, 相関 係数は 0.73 , T值は 2.03 であった。すなわち $\mathrm{T}$ 検定で 差なしとなり, 正の相関は強いが intermetatarsal angle には有意の差は認められなかった。

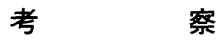

Metatarsus primus varus は外反母趾に対して一次性 に現れるという仮説を証明するためには，少なくとも 2 つの必要条件を満足する必要がある。ひとつは, metatarsus primus varus が存在するもののうちには hallux valgus angle が正常のものがあるということ, もうひとつは, hallux valgus angleが大きいものは常 に metatarsus primus varus を伴うということである. この 2 つの条件のうち，後者の条件が却下された。

よって metatarsus primus varus は外反母趾に対し て一次性に現れるのではないことになる。

すなわち, metatarsus primus varus は, 外反母趾 の成因よりむしろ結果として現れるということがいえ る.

ただし, intermetatarsal angle の大きいものと hallux valgus angle の大きいものとの間では正の相関が 強いので，外反母趾の成因が両者にともに影響を与え ていることが推測された。

\section{結語}

1. Metatarsus primus varus は外反母趾に対して 二次的に現れる.

2. 外反母趾の成因が, intermetatarsal angle の増 大も， hallux valgus angle の増大にも，ともに影響を 与えている.
文献

1) Antrobus, J. N. The primary deformity in hallux valgus and metatarsus primus varus. Clinical Orthopaedics and Related Research. Nr. 184: 251-255, 1984.

2) Hawkins, F. B. : Mitchell, C. L. and Hendrick, D. W. : Correction of hallux valgus by metatarsal osteotomy. J. Bone Joint Surg. 27 : 387-394, 1945.

3) Inman, V. T. : Hallux valgus : a review of etiologic factors, Orthopaedic Clinics of North America. Vol. 5, No. 1, : 59-66, 1974.

4) Mitchell, C. L., Fleming, J. L., Allen, R., Glenny, C., and Sandford, G. A. : Osteotomy-bunionectomy for hallux valgus. J. Bone Joint Surg. 40A : 41-60, 1958.

質 問坐長 野村 茂治

外反母趾は横アーチの破綻によるものである，立位 レ線で計測しなければ成因として論ずる場合，また予 防法に結びつけるにしてもせっかくの計測に意味を持 たないと考えるが.

解 答 久留米大学 西見 文紀

単純に立位で撮影すれば良いというものではない。 なぜならば,

(1) 前足部に重心をかけた場合と踵部に重心をかけ た場合は測定值が異なってくること。

(2) 足底面と撮影台の面とでは，3 次元的に必ずし も平行の位置で撮影されるとは限らず, 測定值の誤差 を生ずること.

などの理由があるからで, 撮影台上仰臥位では患者 が意識的に撮影条件を変えられないぶん立位よりもス クリーニングとしては適しているのではないかと考え る. 